\title{
Decolonising Development?
}

\section{Re-claiming Biko and a Black Theology of Liberation within the context of Faith Based Organisations in South Africa ${ }^{1}$ \\ Nadine Bowers Du Toit ${ }^{2}$}

\begin{abstract}
An upsurge in interest with regard to the role of religion in development has also seen an increase in the study of Faith Based Organisations (FBO's). These organisations have been less well studied within the South African context, yet both in light of South African Christianity's colonial and apartheid past - and the practical challenges that arise within a Global South development context such as northern donors, the cultural relevance of programmes and the tension between justice and charity within a South African context (where the face of poverty is still largely black) they should be the subject of academic inquiry. In light of the latter as well a growing trend within Development Studies with regard to decolonial and post-colonial critiques of development, this paper seeks to argue for the relevance of a both Black Consciousness and a Black Theology of Liberation in challenging and re-positioning the identity, role and practical challenges faced by FBOs within the South African context.
\end{abstract}

Keywords: Faith Based Organisations, Black Theology, Black Consciousness, Development Studies, Theology and Development, Diaconia

\section{Introduction}

Although development studies have traditionally neglected the role of religion, there has been a noticeable upsurge of interest in recent years as the place of religious organisations within discourses on civil society becomes more prominent (Clarke 2007:78; Olsen 2008:393; Williams, Coke \& Thomas 2012:1479). Indeed, the Faith Based Organisation (FBO) sector is a prominent player within South African civil society - known for its reach and role in providing social development services to the poorest of the poor. Although largely understudied, questions should be raised with regard to Christian Development Organisations (CDO) - as a sub type of the FBO - positioning considering both their Christian identity - in light of South Af-

1 It should be noted that this article forms part of a National Research Foundation (NRF) Competitive Unrated Grant (CSUR150623120252 - 9918) entitled: "Does faith matter?" Exploring the role of Faith Based Organisations as Civil Society actors.

2 Nadine Bowers Du Toit is an Associate Professor at the Faculty of Theology, University of Stellenbosch. She may be contacted at nbowers@sun.ac.za 
rican Christianity's colonial and apartheid past; and the practical challenges that arise within a Global South development context such as northern donors, the cultural relevance of programmes and the tension between justice and charity within a South African context, where the face of poverty is still largely black ${ }^{3}$.

Community development was not popular in South Africa during the 1970s and 80 s due to "scepticism in government circles about its potential for political change" as it sought to address poverty, which was largely black. It did, however, make headway in both the Black Consciousness Movement ${ }^{4}$ (BCM) and evangelical missionary circles (Swanepoel \& De Beer 1998:10). In fact, the BCM is noted as "perhaps the most important exponent of radical community development (empowerment) in South Africa" and Biko ${ }^{5}$ himself is noted for his involvement in community development (Swanepoel \& De Beer 1998:14). Community Development as practiced by the proponents of Black Consciousness (BC) was, therefore, viewed as an active tool in liberation and, as aforementioned, remains a respected forerunner to the practice of Community Development in SA today. Black theology, which accompanied $\mathrm{BC}^{6}$, also certainly provides possible contextual faith perspectives relevant to FBOs working in a context of poverty and inequality, which still sadly 'has a black face' ${ }^{7}$.

This paper seeks to firstly explore the notion of decolonising within community development and the positioning of the FBO within civil society, before arguing for the relevance of a Black Theology of Liberation in challenging and re-positioning (decolonising) the identity, role and practical challenges faced by the CDO within a postcolonial and post - Apartheid South African context.

\section{Towards defining decolonising development}

Development studies is often critiqued by the decolonial turn as being too Eurocentric and defined by dominant western discourses and practical solutions. Converse-

3 Despite 23 years of democracy, inequality and poverty are still racially skewed (cf. Bhorat \& Van der Westhuizen 2012:4).

4 Hereafter referred to as BCM.

5 Stephan Bantu Biko is widely recognised as the "symbol" of Black Consciousness in South Africa. As leader of the South African Students Organisation (SASO) he championed the need for black people to take their future into their own hands and was banned at the age of 25 for his political activities. He died in police custody at the tender age of 33 . Biko continues to be lauded as one of the brightest intellectual minds of his time (cf. Maluleke 2008:58-60).

6 Hadfield (2016) notes repeatedly in her book "Liberation and Development: Black Consciousness Community Programs in South Africa" the close links between the church and Black Consciousness and notes that churches not only supported the movement, but that one of the first programmes of the BCP was a black church leaders conference (2016:56).

7 It should be noted that Biko himself argues that Black Consciousness (and indeed Black Theology) would be "irrelevant in a homogenous non-exploitative, egalitarian society". "Blackness" and, therefore, "whiteness" must be understood as political and ethical constructs (Tshaka \& Mafokane 2010:534). 
ly, $r$ post-colonial debates are often accused of being too philosophical and indeed even theologies such as Black Theology have been accused of the same (see Tshaka \& Mafokane 2010:544). With regard to this tension, Sylvester (1999:703), for example, underscores that "development studies does not tend to listen to subalterns, and postcolonial studies does not tend to concern itself with whether the subaltern is eating." The need to explore decolonising perspectives of community development in the Global South, are, therefore, key "in light of international growing concern that neoliberal models for development, including reforms that prioritized private-sector economic growth and cut back on state-based social safety nets, have not delivered the social and economic improvements they had promised" (Wutich \& Beresford 2015: 3). Wutich and Beresford $(2015: 3,5)$ explore what decolonising within the context of community development entails and note the following: "belief in an autonomous indigenous identity (as opposed to being defined in relation to Western culture and ideologies)", an "emphasis on building economies that are collective at the local/community level", "promote non-capitalist economies", "collective forms of governance" and "mobilise support from grass-roots social movements".

\section{Current FBOs' positioning with the NGO sector and related challenges}

Although research with regard to FBOs has been on the increase, its agenda has been modest when compared to research of other secular NGOs or multi-lateral agencies (Olsen 2008:393). Within a South African context, there is evidently a dearth of comprehensive research on the current and potential role of FBOs within a broader South African context, which are better reflected in other international studies. The notion of the FBO itself is highly disputed as there currently exists "no generic or typical definition a FBO". Some interpret this broadly as every institution or organisation that has some connection to religion while others use the term in a narrow sense (Swart and Van der Merwe 2010:84) ${ }^{8}$. In this paper, a sub type of the FBO, which our project refers to as the Christian Development Organisation (CDO), will be used to define organisations specifically working in the development sector who claim a Christian faith ethos. This type is best identified by Clarke (2006:840) as Faith-based charitable or development organisations "which mobilise the faithful support of the poor and other social groups, and which fund or manage programmes which tackle poverty and social

8 It should be noted that there are various typologies as identified by authors such as Clarke (2006:840) and Sider and Unrah (2004). Furthermore, the term FBO is itself complex and at times problematic. The complexity of the term must be recognised as the term FBO itself is highly dependent on both religious and geo-political context (James 2009:4). 
exclusion". It should also be noted that CDOs, in this understanding, are recognised as legal entities by the South African Non Profit Organisations ${ }^{9}$ Act and are, therefore, registered as Non Profit Organisations (NPOs) ${ }^{10}$. These organisations work across the development sector with their activities ranging from relief work to community development and advocacy ${ }^{11}$.

It is, nevertheless, clear that Non-Governmental Organisations (NGOs - of which FBOs form a part) play an important role in addressing a range of socioeconomic challenges within our country and are often working at the coalface of poverty and inequality in South Africa addressing the poorest and most vulnerable members of our society (Patel 2012:610). Although South Africa has a "long history of social and community organisation that predates colonialism," Xaba (2016: 5) especially notes the role not only played by missionaries in establishing philanthropic organisations and standing "in support of Africans against colonial interests", but also the manner in which NGOs and FBOs (such as the World Council of Churches and even grassroots organisations) supported the struggle against Apartheid. Patel $(2012: 605 ; 616)$ also makes the point that it was NPOs and indeed FBOs - that, in fact, provided alternative social services and community development to the majority of black populace during the Apartheid era - and highlights the need for NPOs to keep our current government accountable by "maintaining a critical eye".

FBOs are duly recognised by the state as "a natural part of civil society and a natural partner of the state" in a post-Apartheid dispensation (Swart \& Van der Merwe 2010:83). As Swart and Van Der Merwe (2010:84) highlight, the inherent tension for FBOs and perhaps more specifically in our case, CDOs, in negotiating the current development environment is the following:

Issues such as transparency, democracy, accountability and the accessibility of social welfare services of FBOs form a critical part of the discourse. These issues pose a challenge to FBOs with regards to their internal policies such as the composition of their management boards, the selection of staff and their programmatic activities. The critical question in this regard seems to be how FBOs can remain faithful to their unique identity and ethos expressed in their mission statements and internal policy documents, but also be part of the transformational agenda of the social welfare sector.

9 The Non Profit Organisations Act 71 (1997) of the Republic of South Africa.

10 The scope of this paper, therefore, does not include Community Based Organisations (CBO's) or initiatives of local churches that are not registered as NPO's.

${ }_{11}$ Other faith based institutions and initiatives such as local congregations, denominational bodies or Christian tertiary institutions are not included in this definition. 
Indeed, the $\mathrm{FBO} / \mathrm{CDO}$ has a unique identity and currently faces the challenge of whether to "accept a religiously neutral social welfare agenda or to take the risk of a decrease in income if they do not accept the agenda" (Swart \& Van Der Merwe 2010:86). This is no different with regard to international donors, who while acknowledging the role and importance of faith in recent years would still seek to dictate a neutral social welfare agenda within the development agenda. As such, the refunding of organisations is often aligned to measurable outcomes the donor wishes to see -not the faith ethos of the organisation or even the social contexts needs and assets within which the project or organisation is situated (cf. De Wet 2016:9). The latter is a major issue within the broader NGO sector and speaks to the manner in which neo-liberal agendas still dominate - even in the non-profit sector.

Xaba (2016:7) worryingly notes that unlike government's social development departments, NGOs continue to reflect the racial stratification of staff, with their management still largely white and where a "black African director is appointed, the post is stripped of most its powerful functions like financial management and recruitment." This has not been studied within the FBO sector, however, if we take the FBO sector as a smaller reflection of its larger sector then this is still relevant - not least because many FBOs in Cape Town known to the researcher are still largely white led ${ }^{12}$.

Xaba (2016:9) also critiques what he terms the "perpetual tutelage of communities" by NGOs who despite claiming that they are seeking to assist communities to become self-reliant - often only perpetuate the need for their services, skills and expertise. This indeed works against the notion of 'people first'. Commenting on NGOs, De Wet (2016:9) observes that "there is still a lack of understanding of the power that they have due to the difficulties in methodologically researching them". These perspectives highlight the challenges faced by FBO's as civil society actors seeking the transformation of South African society and point to the possible relevance of perspectives such as BCM and BT in engaging them.

\section{Engaging FBOs in light of Black Consciousness and a Black Theology of Liberation}

This section seeks to weave the Black Consciousness of Biko in relation to their involvement in development with Black Theology, with the aim of engaging FBOs' challenges in light of these perspectives. Several issues are problematised within this section, including donor agendas, professionalism and "whiteness", cultural relevance and the notions of liberation versus charity.

${ }^{12}$ Although the most vulnerable in our society are black women and the study of which this research output forms part will consider the gendered nature of development within its broader aims, this equally important intersection has not yet been sufficiently studied in the context of the FBO to be explored here. 


\subsection{Donor agendas}

Donor agendas are clearly problematic for both NGOs and FBOs with the latter facing further scrutiny due to their faith ethos. Strongly put - donor agendas can become the new colonialism as NGOs and FBOs carry out outside-in (and more often than not Northern) agenda that are for the people and not with them (Thaut 2009: 32; cf. Swart and Van der Merwe 2010:869).

$\mathrm{BC}$ argued that Black people themselves had a responsibility to respond to their own challenges. According to Hadfield (2016:49), this was something the BCM at the time felt strongly about - "black development should not rely on external aid because it usually came with strings attached" (especially from the North) and would "compromise the meaning of Black Consciousness through self-help and self-reliance".

In this regard, those students and intelligentsia who worked with them were to take "time to understand communities, listen to the people, hear their stories and their struggles for life, and work with them towards solutions" (Pityana 2007:7). The latter is today recognised within the development sector as a key people -centred development approach $^{13}$. Xaba, however, observes that NGOs often themselves work against this approach in order to continue the need for their "services skills and expertise", rather than journeying alongside the people as fellow travellers in solidarity with communities struggles. Perhaps if we were to interpret this theologically, we would use the term incarnational? "God with us" - Christian development practitioners "with us"? Of course within the context of BCM and Black Theology this must be accompanied by the term liberation. Liberation in this case from donor agendas and demands? After all it is the oppressed who should be setting the agenda: "the message of Black Theology, as already seen, is liberation: to set the downtrodden free" (Mothabi in Buffel 2010:472). Questions can then be asked: What does this tension mean for NGO's seeking to be directed by the agenda of communities and not donors? With this in mind, how can CDOs continue listening to the subalterns/local communities and the needs they seek to serve of facing the tension of Donor agenda determined from outside?

\subsection{Professionalism, power and "whiteness"14}

How much of the perpetual tutelage of communities is not based on the need to continue to receive donor funding and maintain the employment of professional

13 People-centred or people-driven development "has its origin in the concern that the people who are the beneficiaries of the programme/project should have control over the programme/project" (Theron \& Ceasar 2008:103).

${ }^{14}$ Kritzenger (2008:102) notes that white South Africans have "often tended to take their identity as the standard by which everyone else is measured" and that "most white South African's were socialised" as they grew up to express what Steyn (2001: xxvii) calls the "Western colonialist master narrative with all its assumptions of the superiority, special entitlement, and unique destiny of European peoples". 
development workers? Professionalism is not in and of itself out of place in the development sector. Chambers' (1997) classic work entitled: "Whose reality counts? Putting the last first", however, highlights the notion that there is often a power dynamic inherent in development professionalism. Powerful, educated development professionals often fall into the trap (often unconsciously) of denying the realities of poor communities even possibly "seeking to impose on them their own realities", who he refers to as "lowers" in the normalised hierarchies in interpersonal relationships, (Chambers 1997:59). In this framework, local realities are, therefore, not acknowledged or their understanding of the world understood. A Black Consciousness philosophy strongly critiques the notion of outside intervention as well as this power dynamic as Swanepoel \& De Beer observe in the following quote:

The philosophy of Black Consciousness, therefore, expresses group pride and the determination of the black to rise and attain the envisaged self. Freedom is the ability to define oneself with one's possibilities held back not by the power of other people over one, but by one's own relationship with God and to natural surroundings (Swanepoel and De Beer 2008:14).

This is a decided critique on the normalised patters of dominance and subordination within human relationships. In South Africa, this is still more potent as patterns of dominance and subordination were defined in the past (and still today) in terms of race and class - which, to a large degree, still remain connected. Indeed, Biko paid particular attention to the "stratagems of social control of the oppressive classes" and sought to expose "the role of the liberal in denying the oppressed the duty to be their own liberators" (Pityana 2012:8). Biko was critical of white liberals. His critique, Kritzinger (2009:95) argues, was not based on a kind of reverse racism, but rather on the rejection of integration for a completely transformed society. Kritzinger (2009:102), therefore, makes the following salient point:

It is always difficult for (former) oppressors or the beneficiaries of a system of oppression to understand its inner dynamics and devise workable strategies against it, at least if those strategies entail mobilisation of the suffering community and not charitable actions from outside (or above).

Does this mean that there should be no white "liberal" CDO workers? No, yet if as Xaba states, many NGOs are still largely white run - how successful will these efforts be in the long run? ${ }^{15}$ CDOs need to take this particularly seriously in light of the

15 Hadfield (2016:50) notes for example that BC leaders such as Mamphela Ramphele at the time drew a distinction between "self-reliance and insulating oneself from important sources of information and 
Imago Dei. Yes, we are all created in the image of God, but what is being embodied? Tshaka \& Mafokane (2010:541) make the point that both BC and BTL aimed at "developing a positive sense of the black self" and to "instil a sense of self-worth into Black people". If CDO management is still largely white, what message does that send to communities we serve? A picture of a white saviour?

Here, SA development professionals will need to do deep soul searching in terms of recognising the power dynamics at play simply by virtue of their race and class. CDO professionals should be further challenged to reflect not only on the notion of incarnation, but also the demands of contextualisation as flowing out of this from a theological perspective.

\subsection{Contextual relevance}

To take this further still: should CDOs - especially those in service of explicitly faith centred mission statements - not seek out a more contextual theology from which to reflect? Cultural domination is often subtle, but still rests on either the notion of "cultural domination" or "cultural assimilation". According to Vellum (2016:2), a Black Theology of Liberation recognises "that the culture of the subjugated peoples and groups are always deemed worthless compared to the culture of the dominant groups and, therefore, unworthy of consideration and contribution". Bragg (1987:21) observes that as far back as the 1980s, both the Christian church and para church agencies were seen to have accepted uncritically the basic premise of the Western ideal of development". This ideal was based on the notion that economic progress in the majority world (the Global south) should mimic that of the west and would automatically result in social and moral progress as determined by western ideals. Thus, an ethic of black solidarity was an inherent component of Black Consciousness. It was, therefore, argued that students and intelligentsia must "remain connected to their social and cultural roots" (Pityana 2007:7). Of significance, Pityana (2007) notes that this was not only in terms of participation in development projects, but also in how Black people respond to their own challenges as they best understand their socio-cultural contexts. Vellum goes on to state that the future of BTL lies with the "poor and nowhere else" - CDOs will need to reflect on whether they are truly contextually engaged and valuing of local knowledge systems and cultures or whether their own policies and practices continue to "enshrine white superiority and black inferiority" (Vellum 2016:2; cf. Tshaka \& Mafokane 2010:535). How do they read the bible and do they read the bible with those they serve? What kinds of spirituality inform their practices? Do

resources for the successful implementation of whatever task is at hand". This was the pragmatic approach which drew on a wide spectrum of people both nationally and internationally, but which sought to maintain black leadership and autonomy. 
they take black experiences as their point of departure when designing projects and programmes? (Chimhanda 2010:435)

\subsection{Liberation vs charity as development}

It is important to remember in this discussion that despite the recognition of the positive role played by missionary groups during the colonial era in Africa, it is also true that many Faith Based Organisations during this era not only provided "material support in education, health or other social services" but that "in providing such services, they were also concerned with evangelizing among the African population, discouraging what they perceived as ignorance, idleness and moral degeneracy, and promoting their own vision of civilisation" (Manji \& 0'Coil 2002:3). In fact, many of these organisations in their philanthropic capacity even saw "works of benevolence as a solution to social unrest. In short, charity was not only designed to help the poor, it also served to protect the rich" (Manji \& O Coil 2002:7; cf. De Wet 2016:9).

Manji \& 0' Coil (2002:2) issue a stinging critique of NGOs in Africa in their seminal paper, by suggesting that NGOs today "contribute marginally to the relief of poverty, but significantly to undermining the struggle of African people to emancipate themselves from economic, social and political oppression". Here, they find that post-independence, missionary societies soon began to espouse the term 'development', but note that the Modernisation Theory notion of development only replaced 'uncivilised' with 'underdeveloped' and that the "dominant discourse of development was framed not in the language of emancipation or justice, but with a vocabulary of charity, technical expertise, neutrality and deep paternalism (albeit accompanied by the rhetoric of participatory development)" (Manji \& O'Coil, 2002: ). While many FB0s today would reject the Modernisation approach to development and openly profess a participatory agenda - just how much attention is given to the notion of justice within the South African context versus the "every day" work of charity and technical expertise? A case in point is the \#feesmustfall social movement ${ }^{16}$ throughout South Africa, which is seeking to challenge a socio economic and political system that continues to benefit the minority - yet NGOs and FBOs are largely silent in their support. It is interesting to note that it was the student generation of the 1970s that gave rise to the BCM and, in turn, BC practice was deeply rooted in community development, which was seen as issuing

16 This social movement began with \#Rhodesmustfall at the University of Cape Town and is best symbolised by the removal by students of the statue of Cecil John Rhodes as critique of the colonial legacy and a call for decolonised education. It later spread across the country to become \#feesmustfall as students protested against fee hikes and for more equitable access, transformation and decolonised curricula at universities in South Africa. 
from their "liberatory consciousness" - it could not be a mere charitable exercise (Pityana 2012:11). In contrast, BTL challenges CDOs and FBOs to be liberatory in their agenda while noting that the Kingdom's agenda is not charitable assistance or successful projects, but rather liberation and shalom - total restoration (Motlhabi 1986:46, cf. Cone 1987:1). I serve on the board of a CDO whose vision has shifted from more project based development towards equipping and training churches and justice/advocacy. A recent encounter with supporters of this FBO was, however, greatly disillusioning as white, liberal Christians appeared upset that the CDO had shifted from a project based approach to that of training, justice and advocacy ${ }^{17}$.

\section{Conclusion}

This paper sought to take seriously both critiques in engaging the $\mathrm{BC}$ of Biko and BTL with the challenges faced by FBOs within the development sector. These challenges are complex and understudied both nationally and internationally. Furthermore, the paper highlights the manner in which BC and Black Theology could provide the opportunity for decolonised praxis that recognises the importance of indigenous identity and self-reliance, centres the local community and forms part of larger movements for justice and liberation. While, this paper did not seek to offer solutions, but to rather raise questions in light of Black Consciousness and Black Theology of Liberation thinking within the context of the Christian Development Organisation, it poses a direct challenge to normalised patterns of praxis within these organisations.

\section{References}

Bhorat, H. \& Van der Westhuizen, C. 2012. Poverty, inequality and the nature of economic growth in South Africa. Development Policy Research Unit working paper 12/131. UCT. http://www.humanities.uct.ac.za/sites/default/files/image_tool/images/36/ DPRU\%20WP12-151.pdf

Bragg, W. 1987. From Development to Transformation. In V. Samuel \& C. Sugden (eds). The Church in Response to Human Need. Regnum:Oxford

Buffel, O.A. 2010. Black Theology and the black masses: the need of an organic relationship between Black Theology and the black masses. Scriptura. 105(2010): 470-480 Chambers, R. 1997. Whose reality counts? Putting the first last. Zed books: London

17 As far back as the late 1960's Dickenson (1968:78-80) in a World Council of Churches (WCC) publication noted that Christians should not simply sponsor projects that are "designed primarily to meet the needs dictated by charity alone", but that the roots of poverty and inequality should be engaged. 
Chimhanda, F.H. 2010. Black Theology of South Africa and the liberation paradigm. Scriptura. 2010(105): 434-445.

Clarke, G. 2006. Faith matters: Faith-based Organisations, civil society and international development. Journal of International Development, 18(2006): 835-848.

Cone, J. 1986. Speaking the truth: Ecumenism, liberation and Black Theology. Eerdmans: Grand Rapids

De Wet, L. 2016. Silencing the Subaltern: a postcolonial critique of NGO-run Orphanages in Jinja, Uganda. Master of Science in Development Studies. Lund University: Sweden

Hadfield, L.A. 2016. Liberation and Development: Black Consciousness Community Programs in South Africa. Michigan State University: East Lansing

Kritzinger, K. 2008. Liberating Whiteness: engaging with the anti-racist dialectics of Steve Biko. In C. Toit (ed), The Legacy of Stephen Bantu Biko: Theological Challenges. Unisa: Pretoria

Maluluke, T. 2008. 'May the black God stand please!' Biko's challenge to religion. In C. Toit (ed), The Legacy of Stephen Bantu Biko: Theological Challenges. Unisa: Pretoria

Manji, F. \& O' Coil, C. 2002. The missionary position: NGO's and development in Africa. International Affairs. 178(3):567-583

Olsen, E. 2008. Common belief, contested meanings: development and faith based organisational culture. Tijdschrift voor Economische en Sosiale Geographie. 99(4):393-405.

Patel, L. 2012. Developmental social policy, social welfare services and the non-profit sector in South Africa. Social Policy and Administration. 46(6):603-610.

Pityana, B. 2007. Reflections on 30 years since of the death of Steve Biko: a legacy revisited. Steve Biko Lecture at the University of South Africa. Unpublished paper http:// uir.unisa.ac.za/bitstream/handle/10500/110/Steve\%20Biko\%20Lecture\%202007\%20 doc\%20final\%20_2_pdf?sequence $=1$

Pityana. B. 2012. Black Consciousness, Black Theology, student activism and the shaping of a new South Africa. Steve Biko Memorial lecture in Europe. Unpublished paper http://www.sahistory.org.za/sites/default/files/Steve\%20Biko\%20Memorial\%20 Lecture-Europe\%202012.pdf

Sider, R.J. \& Unruh, H.R. 2004. 'Typology of Religious Characteristics of Social Services and Educational Organizations and Programs,' Non-Profit and Voluntary Sector Quarterly. 33(1): 109-134.

Swanepoel, H. \& De Beer, F. 2008. Community Development and beyond: issues, structures and procedures. Van Schaik: Pretoria

Swart, I. \& Van Der Merwe, W. 2010. Towards conceptualising faith-based organisations in the context of social welfare and development in South Africa. In Swart, I., Green, S., Erasmus, J. \& Rocher, H. (eds) Religion and Social Development in PostApartheid South Africa. Sun Media: Stellenbosch

Sylvester, C. 1999. Development studies and post-colonial studies: Disparate tales of the Third World. Third World Quarterly. 20(4):703-721.

Thaut, L. 2009. The role of faith in Christin faith-based humanitarian agencies: constructing the taxonomy. Voluntas. 20(4): 319-350. 
Theron, F. \& Ceasar, N. 2008. Participation - a grassroots strategy for development management. In Theron, F. (ed). The development change agent: a micro-level approach to development. Van Schiak: Pretoria

Tshaka, R. 2010. The continued relevance of Black Liberation Theology for democratic South Africa today. Scriptura. 105(2010):532-546

Vellum, V. 2016. The Decolonization of Theology: an epistemological challenge and opportunity. Decolonizing Theology Conference at the University of Stellenbosch. Unpublished paper.

Williams, A, Coke, B. \& Thomas, S. 2012. Co-constituting neo-liberalism: faith based organisations, co-option, and resistance in the UK. Environment and Planning. 44(2012):1479-1501

Wutich, A. \& Beresford,M. 2015. Community development in 'Post-Neoliberal Bolivia': decolonization or alternative modernizations? Community Development Journal (2015): 1-22

Xaba, T. 2016. From public-private partnerships to private-public stick'em ups! NGOism, neoliberalism, and social development in post-apartheid South Africa. International Social Work. 1-11. 